\title{
Water Quality Pollutants and Health Risk assessment for Four Different Drinking Water Sources
}

\author{
MiaomiaoTian, Wenzhao Li*, MeijuanRuan, JingWei and WeiweiMa \\ ${ }^{1}$ Key Laboratory of Food Nutrition and Safety of Ministry of EducationTianjin University of Science and Technology, Tianjin 300457 , \\ P.R.china
}

\begin{abstract}
Drinking water quality has become a great concern to the whole society, especially in heavily polluted rural areas. This paper analyzes the water quality of 100 water supping the US Environmental Protection Agency's (USEPA) recommended health risk assessment model. The results showed that the microbial indicators exceeded the standard in the whole year, and some of the water supply units which lead, nitrated and dissolved solids exceeding the standard. The model recommended by EPA is applied to establish risk assessment model for health risk assessment of adults in wet and dry seasons, respectively. Results of HRA indicated that carcinogenic risk of chromium was $7.61 \mathrm{E}-05 \mathrm{a}^{-1}$ and the risk value of arsenic was $9.92 \mathrm{E}-06 \mathrm{a}^{-1}$ which exceed the maximum acceptable risk level recommended by USEPA 5.0x $10^{-5}$ closely to the ICPR recommendation $1.0 \times 10^{-6}$. Meanwhile we conduct health risk assessment (HRA) on relevant non-carcinogenic indicators: nitrate is $2.95 \mathrm{E}-09 \mathrm{a}^{-1}$, the risk value of fluoride $(\mathrm{F})$ is $2.49 \mathrm{E}-09 \mathrm{a}^{-1}$, the risk value of lead is $2.39 \mathrm{E}-09 \mathrm{a}^{-1}$ and copper $(\mathrm{Cu}) 9.00 \mathrm{E}-10 \mathrm{a}-1$ exceeds the maximum acceptable risk level risk value recommended by USEPA $1.0 \times 10^{-9}$. The above indicators require priority control and management of pollutants that are prioritized and managed.
\end{abstract}

\section{Introduction}

Water is the source of life, accounting about $70 \%$ of the human body. It is the basic necessities for human survival and social development which is the essential materials for daily production and life. Safe and clean drinking water is vital to human health and also an important indicator to measure social development and human life quality ${ }^{[1]}$ ( Chang,2013). In recent years, with the development of the industrialized society, the environment has been deteriorated leading to water pollution incidents. More and more drinking water sources have brought great threats to the health of the people. The problem of rural drinking water safety is more prominent. Due to lack of necessary disinfection and treatment facilities, people have poor quality drinking water in rural areas rural ${ }^{[2]}$ (Han Bing2015), so we should pay attention to drinking water and health problems.

This research lies to monitor and analysis of drinking water quality in rural areas, grasping the changes of water quality in rural areas and build drinking water monitor the network, understanding the changes in water quality in different season to provide guidance for the healthy life of the people.

Health risk assessment (HRA) emerged after the 1980s. It uses risk as an evaluation index to link environmental pollution with human health and quantitatively describing the risk of pollution to human health $^{[3]}$ (Han Xiaogang 2011, )Various studies related to HRA has been conducted using the method recommended by the USEPA around the world ${ }^{[4]}$ (Tornqvist, 2011; Yu et al, 2017). By evaluating the level of harm to human health from water pollution and acceptable risk level of the human body, health risk assessment (HRA) can use as a guidance by administrative sector in water environment protection, pollution remediation and water environment risk management ${ }^{[5]} \quad(($ Khadam and Kaluarachchi, 2003; Kavcar et al. 2009; )

In order to understand the health risks of drinking water quality in rural areas, we tested 100 rural waters, we sampled waters from four different water sources in the area. We analyzed local water quality testing during dry and wet season respectively judging the water quality of the area and analyzing the characteristics of water quality changes during in different season. We use health hazard risk assessment model recommended by the US Environmental Protection Agency (USEPA) to analyze five kinds of the carcinogenic substances and twelve kinds of non-carcinogenic substances in drinking water. The study can provide a basis for local governments to effectively manage water quality and provide a reference for water quality management in other rural areas.

\section{Material and Methods}

\subsection{Study area}

*Corresponding author:E -mail: 2695126653@qq.com 
According to the deployment and requirements of the drinking water monitoring work plan, Sample collecting and analysis fifty samples from four different source of water were collected in wet and dry season respectively. The type of water source include 8 river water sources, 12 deep well water sources, 48 shallow water sources and 32 reservoir water sources (Fig1). The sampling method, procedures and conservation were submitted to the Standard Test Method for Drinking Water(GB/T 5750---2006).

$$
\begin{aligned}
& \text { - river water sources } \\
& \text { - reservoir water sources } \\
& \text { - shallow water sources } \\
& \text { - deep well water sources }
\end{aligned}
$$

Fig. 1 Distribution of different water source types

\subsection{The indicators of Water quality test}

According to the routine water quality testing indicators in the "Sanitary Standard for Drinking Water" (GB5749-2006) and the "Groundwater Quality Standards" (GB/T 14848-2017), We identified 37 indicators including 4 routine microbiological indicators, 11 toxicological routine indicators, 17 sensory traits and general chemical indicators and 5 other indicators. See Table 1 for details.

\subsection{Health risk assessment method}

Defined by the United States Environmental Protection Agency (USEPA), human health risk assessment is the process to estimate the nature and probability of adverse health effects in humans who may be exposed to chemicals in contaminated environment ${ }^{[6]}$ ( $\mathrm{Li}$ et al., 2014)。

Table1. The indicators of Water quality test

\begin{tabular}{c|l}
\hline $\begin{array}{c}\text { Microbial routine indicators } \\
\text { (4 items) }\end{array}$ & $\begin{array}{l}\text { Total Cruciform, heat-resistant } \\
\text { cruciform, Escherichia coil }\end{array}$ \\
\hline $\begin{array}{c}\text { Toxicological routine } \\
\text { indicators (11 items) }\end{array}$ & $\begin{array}{l}\text { As, } \mathrm{Cd}, \mathrm{Cr}^{6}+, \mathrm{Pb}, \mathrm{Hg}, \mathrm{Se}, \\
\text { cyanide, nitrate, chloroform, } \\
\text { carbon tetra chloride, }\end{array}$ \\
\hline $\begin{array}{c}\text { Sensory traits and general } \\
\text { chemical indicators } \\
(17 \text { items })\end{array}$ & $\begin{array}{l}\text { Chromatic, turbidity, odor and } \\
\text { taste, visible to the naked eye,p } \\
\text { H, Al,Fe, Mn, Cu Zn, chloride, } \\
\text { sulfate, total dissolved solids, } \\
\text { total hardness, oxygen } \\
\text { consumption, volatile phenol, } \\
\text { anionic synthetic detergent }\end{array}$ \\
\hline Other indicators (5 items) & $\begin{array}{l}\text { Free residual chlorine, } \\
\text { monochromatic, ozone } \\
\text { Chlorine dioxide }\end{array}$ \\
\hline
\end{tabular}

Defined by the United States Environmental Four steps are recommended by USEPA in health risk assessment: (1) hazard identification: to determine whether a certain contaminant can cause adverse effects on human body by identifying the toxicological characteristics (Li and Ping, 2008); In this part ,We selected chemical carcinogenic pollutant factors include arsenic (As), cadmium (Cd), chromium (Cr6+), chloroform and carbon tetrachloromethane as a detection index for carcinogenic toxins and non-carcinogenicity indicators include lead $(\mathrm{Pb})$, mercury $(\mathrm{Hg})$, selenium $(\mathrm{Se})$, manganese $(\mathrm{Mn})$ copper $(\mathrm{Cu})$ zinc $(\mathrm{Zn})$ iron $(\mathrm{Fe})$ fluoride (F) cyanide $(\mathrm{CN})$ nitrate Phenol nitrate, ammonia nitrogen.

(2) dose-response assessment: the specific relationship between the exposure dose of contaminants and the probability of adverse reactions of exposed population is obtained in this step; The values of carcinogenic coefficient (SF) and reference dosage (RFD) used in this study are shown in Table 2 and Table 3(USEPA, 2012).

(3) Exposure assessment: the process of quantitative or qualitative estimation of exposure factors, including exposure pathways, body parameters, exposure frequency, duration of exposure, etc (USEPA, 1992); drinking water is mainly considered to drinking water, so the direct ingestion of drinking water is the only pathway considered in this study. The exposure can be expressed with formula: 
Table 2. The SF of different carcinogenic chemical

\begin{tabular}{cccccc}
\hline carcinogenic & As & $\mathrm{Cd}$ & $\mathrm{Cr}$ & chloroform & $\begin{array}{c}\text { carbon } \\
\text { tetrachloromethane }\end{array}$ \\
\hline $\begin{array}{c}\mathrm{SF} \\
\left(\mathrm{mg} \cdot \mathrm{kg}^{-1} \cdot \mathrm{d}^{-1}\right)\end{array}$ & 15 & 6.1 & 41 & 0.046 & 0.07 \\
\hline
\end{tabular}

Table 3. The RFD of different non carcinogenic chemical

\begin{tabular}{ccccccc|c}
\hline non-carcinogenic & $\mathrm{Pb}$ & $\mathrm{Hg}$ & $\mathrm{Se}$ & $\mathrm{Mn}$ & $\mathrm{Cu}$ & $\mathrm{Zn}$ \\
\hline $\begin{array}{c}\text { RFD } \\
\left(\mathrm{mg}_{\mathrm{kg}} \mathrm{kg}^{-1} \mathrm{~d}^{-1}\right)\end{array}$ & 0.0014 & 0.0003 & 0.005 & 0.14 & 0.005 & 0.3 \\
\hline $\begin{array}{c}\text { non-carcinoge } \\
\text { nic }\end{array}$ & $\mathrm{Fe}$ & $\mathrm{F}$ & $\mathrm{CN}$ & $\begin{array}{c}\text { Volatile } \\
\text { phenol }\end{array}$ & Nitrate & $\begin{array}{c}\text { ammonia } \\
\text { nitrogen }\end{array}$ \\
\hline $\begin{array}{c}\text { RFD } \\
(\mathrm{mg} . \mathrm{kg}-1 . \mathrm{d}-1)\end{array}$ & 0.3 & 0.06 & 0.037 & 0.1 & 1.6 & 0.97 \\
\hline
\end{tabular}

$$
D \mathrm{i}=\frac{C \times I_{R} \times E_{F} \times E_{D}}{B_{W} \times A T}
$$

where, Di is the exposure dose through ingestion of water ( $\mathrm{mg} / \mathrm{kg}$ per day), $\mathrm{C}$ is the concentration of chemicals in water $(\mathrm{mg} / \mathrm{L})$, IR is the ingestion rate (L/day), EF represents the exposure frequency $(\mathrm{EF}=365$ days/year), $\mathrm{ED}$ is the exposure duration $(\mathrm{ED}=70$ years for carcinogenic risk and 30 years for non carcinogenic risk), BW is the average body weight $(\mathrm{kg})$, and AT refers to the average time representing the period over which exposure is averaged (AT $=70$ years for carcinogenic risk and 30 years for non carcinogenic risk) (USEPA, 2011).

(4) risk characterization: a quantitative description of the magnitude and uncertainty of risk by integrating the data obtained from previous steps (Ma, 2002). Risk can be classified into carcinogenic risk and non-carcinogenic risk according to the toxicity of substances. The risk models recommended by the EPA are shown as following (USEPA, 2000): The exposure can be expressed with formula:

$$
D i=\frac{2.2 \times C_{i}}{70}
$$

$D_{i}$ is the exposure dose through ingestion of drinking water $\left(\mathrm{mg} / \mathrm{kg}\right.$ per day), $\mathrm{C}_{\mathrm{I}}$ is the concentration of chemicals in drinking water $(\mathrm{mg} / \mathrm{L}), 2.2$ equal to IR is the ingestion rate (L/day) is the ingestion rate $(\mathrm{L} /$ day), $\mathrm{EF}=1$ Considering one year as unit.

$$
R_{i}^{c}=\left[1-\exp \left(-D_{i} \mathrm{q}_{i}\right)\right] / 70
$$

$$
\begin{aligned}
R^{C} & =\sum_{1}^{\mathrm{n}} R_{i}^{c} \\
R_{i}^{n} & =\frac{D i / R f D i \times 10^{-6}}{70} \\
\mathrm{R}^{\mathrm{n}} & =\sum_{i=1}^{l} R_{i}^{n}
\end{aligned}
$$

Where $\mathrm{R}^{\mathrm{C}}$ and $\mathrm{R}^{\mathrm{n}}$ are the carcinogenic and non-carcinogenic risks per year, respectively, is the carcinogenic coefficient of carcinogenic chemical, RFD is the reference dose of non carcinogenic chemical i. 70 per life expectancy.

\subsection{Evaluation criteria}

The water quality test results were evaluated according to the "Standards for Sanitary Drinking Water" (GB 5749-2006).

The greater the value of $\mathrm{R}$, the greater the health risk caused by the carcinogen, namely the higher the probability of cancer causing the pollutant. It usually uses the maximum acceptable of carcinogens risk $5 \times 10^{-5} \mathrm{a}^{-1}$ recommended by the International Commission on Audiological Protection (ICRP) and $1.0 \times 10^{-6}$ recommend by USEPA. The maximum acceptable value of non carcinogens is $1.0 \times 10^{-9}$ recommended by USEPA.

\section{Results and discussion}

\subsection{Single indicator test results}

Among the microbial indicators, only Escherichia coil meets the pass rate was $100 \%$, the total number of colonies, heat-resistant californium and total californium are all unqualified, the pass rate respectively is $84 \%$, 


\section{$72 \%, 72 \%$}

In the toxicological indicators, the pass rate of $\mathrm{Pb}$ is $94 \%$ and the pass rate of nitrate is $88 \%$ those are unqualified. Other indicators, including $\mathrm{As}, \mathrm{Cd}, \mathrm{Cr}^{6+}, \mathrm{Hg}$, $\mathrm{Se}, \mathrm{CF}^{-}, \mathrm{CN}^{-}$chloroform and tetra, the concentration of those are in line with the national sanitary standard for drinking water GB5749-2006, the pass rate of those are $100 \%$;

In sensory traits and general chemical indicators, $\mathrm{Mn}$, sulfate, total dissolved solids and total hardness were $98 \%$. Other indicators included $\mathrm{pH}, \mathrm{Al}, \mathrm{Fe}, \mathrm{Cu}, \mathrm{Zn}$, chloride, oxygen consumption, volatile phenol and LAS concentrations are in line with the national drinking water hygiene standards "GB5749-2006".

\subsection{Analysis of changes in unqualified indicators during dry and wet season}

Comparing unqualified indicators in the dry season and the wet season, it found that the lowest pass rate was the microbial index. The qualified rate of the heat-resistant cruciform and total cruciform bacteria is $72 \%$, the qualified rate of the total number of colonies is $84 \%$. There is no change in the pass rate during the dry season and wet season (Fig2)

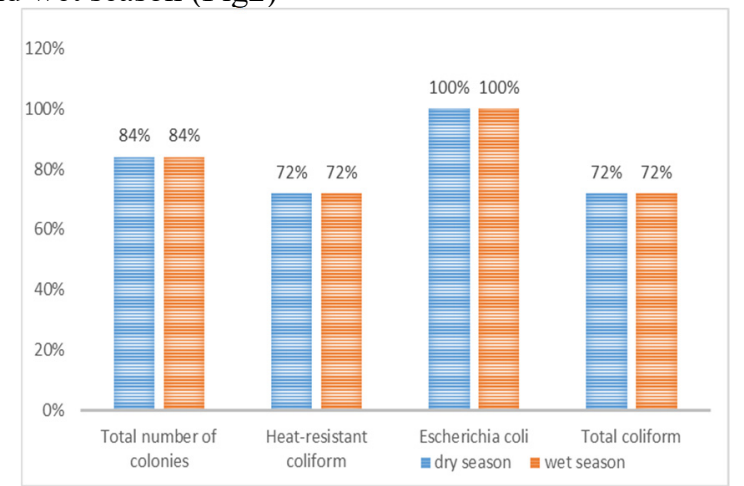

Fig.2. Pass rate of microbial indicators during dry season and wet season

The pass rate of $\mathrm{Pb}$ was $94 \%$ in the dry season and $92 \%$ in the rain season; the pass rate of nitrate was $88 \%$ in the dry season and $84 \%$ in the rain season; the pass rate of $\mathrm{Mn}$ is $92 \%$ in the dry season and $86 \%$. From the above data, it can be seen that the pass rate of $\mathrm{Pb}, \mathrm{Mn}$ and nitrate has decreased in the wet season(Fig3)



Fig.3. Pass rate of $\mathrm{Pb} \mathrm{Mn}$ and nitrate during dry season and wet season
The qualified rate of total dissolved solids is $98 \%$ in the dry season and $98 \%$ in the wet season; the pass rate of the total hardness is $98 \%$ in the dry season and $100 \%$ in the wet season; the pass rate of the sulfate season is $98 \%$ in the dry season and $100 \%$ in wet season. From the above data, it can be seen that the qualified rate of the total hardness and sulfate has increased in the rain season.(Fig4)

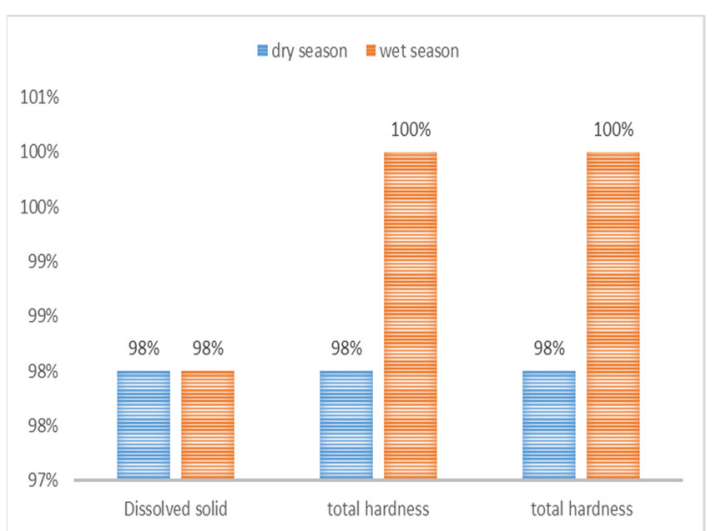

Fig.4. Pass rate of Dissolved solid, total hardness, and total hardness during dry season and wet season

\subsection{Analysis of water source types of unqualified indicators}

It can be seen that the main source of water of inappropriate indicators is shallow well water source, accounting for $90 \%$. The main reason is that the shallow well water usually directly passed through the hand pump or the machine to take water into family life without any disinfection measures, so the microbial indicators are seriously exceeded. In addition, due to the shallow well water source is very susceptible to atmospheric precipitation, surface runoff, environmental pollution and other factors, the shallow well water quality is relatively poor.

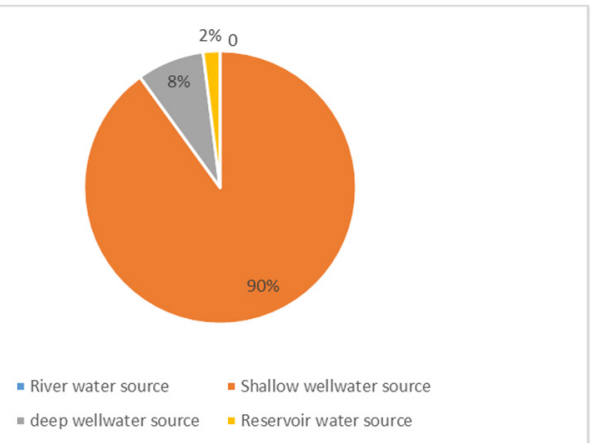

Fig.5 The proportion of unqualified water sourc 
Table 4. Analysis of carcinogen health risks

\begin{tabular}{|c|c|c|c|c|}
\hline The element & $\begin{array}{c}\text { dry } \\
\text { season }\end{array}$ & $\begin{array}{l}\text { Wet } \\
\text { season }\end{array}$ & $\begin{array}{l}\text { Annual health } \\
\text { risk values }\end{array}$ & $\begin{array}{l}\text { The maximum } \\
\text { acceptable value } \\
\text { recommended by } \\
\text { ICPR }\end{array}$ \\
\hline As & 4.66E-06 & $5.26 \mathrm{E}-06$ & $9.92 \mathrm{E}-06$ & $5.0 \times 10-5$ \\
\hline $\mathrm{Cd}$ & $1.09 \mathrm{E}-06$ & $1.24 \mathrm{E}-06$ & $2.33 \mathrm{E}-06$ & $5.0 \times 10-5$ \\
\hline $\mathrm{Cr}^{6+}$ & $3.75 \mathrm{E}-05$ & $3.86 \mathrm{E}-05$ & $7.61 \mathrm{E}-05$ & $5.0 \times 10-5$ \\
\hline chloroform & $1.76 \mathrm{E}-07$ & $2.25 \mathrm{E}-07$ & $4.01 \mathrm{E}-07$ & $5.0 \times 10-5$ \\
\hline $\begin{array}{r}\text { carbon } \\
\text { chlorinate }\end{array}$ & $1.13 \mathrm{E}-08$ & $1.10 \mathrm{E}-08$ & $2.23 \mathrm{E}-08$ & $5.0 \times 10-5$ \\
\hline $\begin{array}{l}\text { Total health risk } \\
\text { values }\end{array}$ & 4.34E-05 & $4.54 \mathrm{E}-05$ & $8.88 \mathrm{E}-05$ & \\
\hline
\end{tabular}

Table 5. health risk analysis of non-carcinogens

\begin{tabular}{|c|c|c|c|c|}
\hline The element & $\begin{array}{l}\text { Dry } \\
\text { season }\end{array}$ & $\begin{array}{l}\text { Wet } \\
\text { season }\end{array}$ & $\begin{array}{l}\text { Annual health } \\
\text { risk values }\end{array}$ & $\begin{array}{l}\text { The maximum acceptable } \\
\text { value recommended by ICPR }\end{array}$ \\
\hline $\mathrm{Pb}$ & $1.22 \mathrm{E}-09$ & $1.17 \mathrm{E}-09$ & $2.39 \mathrm{E}-09$ & $1.0 \times 10^{-9}$ \\
\hline $\mathrm{Hg}$ & $1.12 \mathrm{E}-20$ & $1.02 \mathrm{E}-20$ & $2.14 \mathrm{E}-20$ & $1.0 \times 10^{-9}$ \\
\hline $\mathrm{Se}$ & $5.68 \mathrm{E}-11$ & $4.49 \mathrm{E}-11$ & $1.02 \mathrm{E}-10$ & $1.0 \times 10^{-9}$ \\
\hline $\mathrm{Mn}$ & $3.22 \mathrm{E}-18$ & $3.24 \mathrm{E}-18$ & $6.46 \mathrm{E}-18$ & $1.0 \times 10^{-9}$ \\
\hline $\mathrm{Cu}$ & $4.51 \mathrm{E}-10$ & $4.49 \mathrm{E}-10$ & $9.00 \mathrm{E}-10$ & $1.0 \times 10^{-9}$ \\
\hline $\mathrm{Zn}$ & $2.54 \mathrm{E}-11$ & $4.02 \mathrm{E}-11$ & $6.56 \mathrm{E}-11$ & $1.0 \times 10^{-9}$ \\
\hline $\mathrm{Fe}$ & $2.84 \mathrm{E}-11$ & $2.80 \mathrm{E}-11$ & $5.64 \mathrm{E}-11$ & $1.0 \times 10-9$ \\
\hline $\mathrm{F}$ & $1.33 \mathrm{E}-09$ & $1.16 \mathrm{E}-09$ & 2.49E-09 & $1.0 \times 10-9$ \\
\hline $\mathrm{CN}$ & $1.21 \mathrm{E}-11$ & $1.21 \mathrm{E}-11$ & $2.42 \mathrm{E}-11$ & $1.0 \times 10-9$ \\
\hline $\begin{array}{l}\text { Volatile } \\
\text { phenol }\end{array}$ & $4.49 \mathrm{E}-12$ & $4.49 \mathrm{E}-12$ & $8.98 \mathrm{E}-12$ & $1.0 \times 10-9$ \\
\hline nitrate & $1.60 \mathrm{E}-09$ & $1.35 \mathrm{E}-09$ & 2.95E-09 & $1.0 \times 10-9$ \\
\hline $\begin{array}{l}\text { Ammonia } \\
\text { nitrogen }\end{array}$ & $5.05 \mathrm{E}-11$ & $2.63 \mathrm{E}-11$ & $7.68 \mathrm{E}-11$ & $1.0 \times 10-9$ \\
\hline
\end{tabular}

\subsection{Health risk assessment and sensitivity analysis}

\subsubsection{Health risk analysis of carcinogenic pollutants}

The total health risk value of chemical carcinogens throughout the year was $8.88 \mathrm{E}-05$, exceeding the maximum acceptable value of $5.0 \times 10^{-5}$ recommended by ICPR and the risk level was at a medium level. The health risk value of carcinogenic pollutants from high to low is $\mathrm{Cr}^{6+}>\mathrm{As}>\mathrm{Cd}>$ chloroform $>$ carbon chlorinate. The health risk value of $\mathrm{Cr}^{6+}$ element is 7.61E-05, which accounts for the total health risk value $85.70 \%$, exceeding the maximum acceptable value recommended by ICPR $5.0 \times 10^{-5}$, the annual health risk value of As is $9.92 \mathrm{E}-06$, accounting for $11.17 \%$ of the total health risk value. The health risk value of $\mathrm{Cd}$ is $2.33 \mathrm{E}-06$, which is $2.62 \%$ of the total health risk value. In addition, the health risk values for chloroform and carbon chlorinate are 4.01E-07 and 2.23E-08 respectively which health risk is lower than acceptable limits. It can be seen that the 
main risk factors for carcinogens are chromium, cadmium and arsenic. (Table 4 )

\subsubsection{Health risk analysis of non-carcinogenic pollutants}

The total health risk value for non-carcinogens throughout the year was $1.66 \mathrm{E}-08$, exceeding the maximum acceptable value $1.0 \times 10^{-9}$ recommended by ICPR. The health risk values of carcinogenic pollutants are from nitrate to fluoride $>$ lead $>$ copper $>$ selenium. Other indicators are in line with health risks and can be ignored. The main indicators for the excessive consideration were nitrates and fluorides. Nitrate is a kind of indicator for evaluating the pollution of water bodies by organic matter, chemical fertilizer application, sewage irrigation, Waste feces, industrial nitrogenous waste, and nitrogen-containing waste gas emitted from fuel combustion under natural conditions, after leaching and decomposition by precipitation, form nitrate into rivers, lakes and rainwater, which easily lead to nitrate fluoride in water increase. (Table 5 )

\section{Conclusions}

1 The overall health and safety of rural drinking water sources are not ideal for the reason that the microbial indicators exceed the standard, followed by lead, nitrate and manganese elements, etc which need to be monitored and managed in a key manner.

2 In four different drinking water sources, shallow well water sources have the most problems, because shallow well water is susceptible to rainfall, agrochemical, environmental pollution and other factors, therefore shallow well water sources need to adopt key disinfection and sterilization measures.

3 Among the carcinogen health risk assessment indicators, the health risk value of $\mathrm{Cr}^{6+}$ element is the largest, exceeding the maximum acceptable range which needs to control concentration. Secondly, the health risk value of As element and $\mathrm{Cd}$ element are close to the boundary of health risk range. Other elements can be ignored.

4 Among the non-carcinogen health risk assessment indicators, the health risk value of fluoride elements are the largest, exceeding the maximum acceptable range, and key monitoring and management is needed to control the concentration. Secondly, the health risk value of $\mathrm{Pb}$ element and nitrate element is close to the boundary of health risk range. Other elements that monitor changes in their concentration are negligible.

\section{References}

1. Gu B, Ge Y, Chang S X, et al. Nitrate in groundwater of China: Sources and driving forces[J]. Global Environmental Change, 2013, 23(5):1112-1121.

2. Han B, Jie L I, Zhang J. 2014 monitoring and analysis of drinking water in rural areas in Jining[J].
Journal of Jining Medical University, 2015.

3. Han Xiaogang Urban water quality risk assessment and emergency treatment methods [D]. Xi'an University of Architecture and Technology, 2011,

4. Kavcar, P., Sofuoglu, A., Sofuoglu, S.C., 2009. A health risk assessment for exposure to trace metals via drinking water ingestion pathway. Environ. Health 212, 216-227.

5. Khadam, I.K., Kaluarachchi, J.J., 2003. Multi-criteria decision analysis with probabilistic risk assessment for the management of contaminated groundwater. Environ. Impact Assess. Rev. 23, 683721.

6. Li, P.Y., Wu, J.H., Qian, H., Lyu, X.S., Liu, H.G., 2014. Origin and assessment of groundwater pollution and associated health risk: a case study in an industrial park,northwest China. Environ. Geochem Health 36, 693-712.

7. USEPA (U.S. Environmental Protection Agency), 2008. Child-Specific Exposure Factors Handbook. US Environmental Protection Agency, Washington, DC (600/R-06/096F).

8. USEPA (U.S. Environmental Protection Agency), 2011. Exposure factors handbook 2011 edition (final). US Environmental Protection Agency, Washington, DC (EPA/600/R09/052F).

9. USEPA (U.S. Environmental Protection Agency), 1992. Guidelines for Exposure Assessment. Federal Register 57. pp. 22888-22938.

10. USEPA (U.S. Environmental Protection Agency), 2012. Integr. risk Inf. Syst. (IRIS). 